\title{
Roundtable
}

\section{Transgenes and national boundaries - The need for international regulation}

\author{
Muthukumar BAGAVATHIANNAN ${ }^{1 *}$ and Rene VAN ACKER ${ }^{2}$ \\ 1 Department of Plant Science, The University of Manitoba, Winnipeg, R3T 2N2, Canada \\ 2 Department of Plant Agriculture, The University of Guelph, Ontario, N1G 2W1, Canada
}

\begin{abstract}
What happens when one nation cultivates a transgenic crop variety but neighboring nations do not? Using alfalfa as a case study, we argue that the potential for international transgene flow is substantial, and therefore, the need for international cooperation in regulatory decisions concerning transgenic crops is imperative. Alfalfa (Medicago sativa, L.) is the major forage crop in North America. Recently, genetically modified (GM) alfalfa received a moratorium on further cultivation in the US on the grounds that the approvals were based on inadequate environmental impact assessments. With their deep root system, symbiotic nitrogen fixation, prolific seed production and prolonged dormancy, alfalfa plants are capable of establishing self-perpetuating (feral) populations in unmanaged environments. Given what is known about alfalfa pollen dispersal, such feral populations could facilitate gene flow between GM and non-GM fields. The border between the US and Canada, particularly in farming areas, is very narrow ( $<10 \mathrm{~m}$ wide). We surveyed along the US-Canada border and found both alfalfa fields and potentially feral alfalfa plants in the ditches along the border. Our survey results provide evidence of the possibility of cross-border transgene flow, suggesting a need for international co-operative risk assessment initiatives between the US and Canada. Such situations could occur for other crops, in other international border regions as well.
\end{abstract}

Keywords: feral alfalfa / gene flow / international border / risk assessment / trait movement

Organisms that are deregulated in one country can be adventitiously present at sites along the border regions of a neighboring country. For example, in the US, genetically-modified (GM) glyphosate-resistant (GR) alfalfa (Medicago sativa, L.) has been deregulated and was available for cultivation. But it has not been approved for commercial cultivation in Canada. If GM alfalfa were grown in regions along the US-Canada border, transgene movement could occur from the US into adjacent alfalfa populations in Canada. We argue that there exist possibilities for international gene flow among the alfalfa populations that occur in the border regions between the US and Canada.

Before going into the details of international gene flow in alfalfa, let us detail the current situation of GM alfalfa in the US. The herbicide-resistant alfalfa was deregulated in 2005. It subsequently raised concerns among the conventional and organic growers over the adventitious presence of transgenes and associated market risks and

*Corresponding author: umbagava@cc.umanitoba.ca environmental damages (WORC, 2005). On March 12, 2007, Charles Breyer, a federal district judge in the United States District Court for the Northern District of California issued a moratorium on further sales and cultivation of GR alfalfa, while existing plantings were allowed to remain in place (Fox, 2007). The court stated that the Animal and Plant Health Inspection Service (APHIS) violated the National Environmental Protection Act (NEPA) by choosing not to prepare an Environmental Impact Statement (EIS) before it deregulated GR alfalfa in 2005 (USDC, 2007a).

Effective March 12, 2007, USDA returned the GR alfalfa to regulated status in compliance with the court injunction. Further, the defendants' request to reconsider the preliminary injunction was denied by the court on May 3, 2007, and the injunction was made permanent pending the preparation of an EIS by APHIS (USDC, 2007b). However, alfalfa fields that were planted prior to the injunction in 2007 continue to produce, following the regulations imposed by the court as outlined in the amended order issued on July 23, 2007 (USDC, 2007c). 


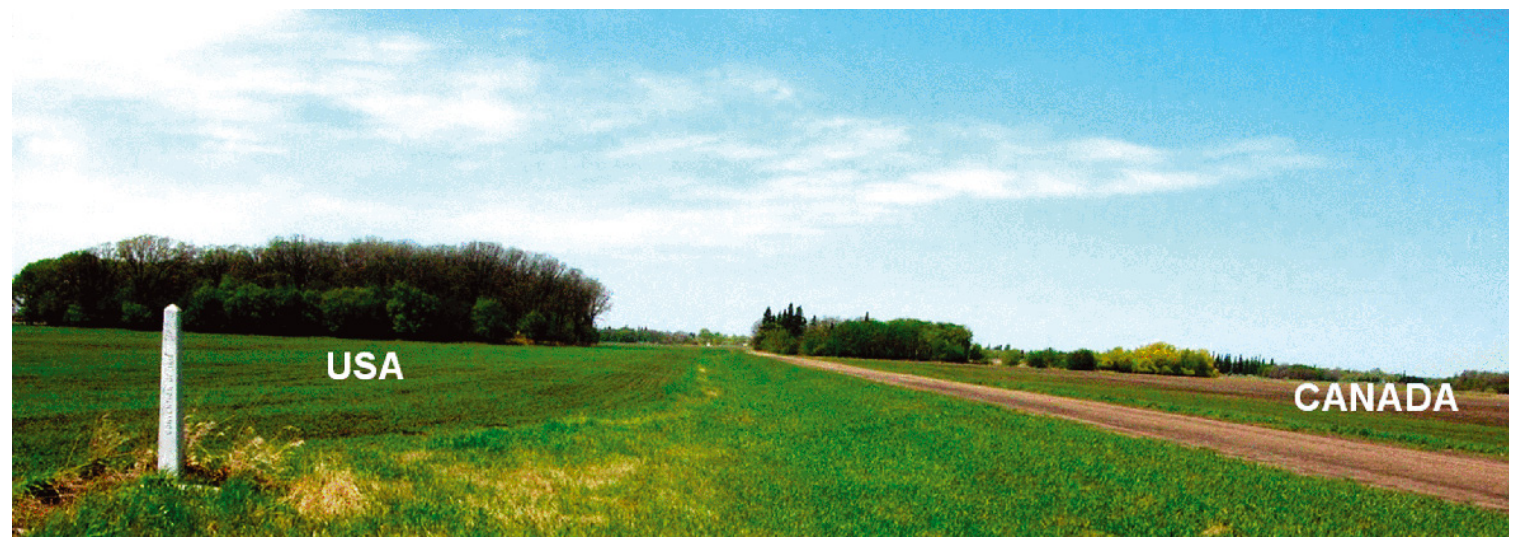

Figure 1. A photograph of the US-Canada border near Emerson, Manitoba, May, 2007. The ditch along the zero mile road is less than $5 \mathrm{~m}$ wide.

On September 2, 2008, the US Ninth Circuit Court ruled against the appeal to lift the injunction on GR alfalfa, and ruled for the injunction to continue in effect.

The ecology and biology of alfalfa is favorable for long-distance gene flow. Alfalfa is a perennial, highly outcrossing crop species, which is predominantly pollinated by insects such as honeybees (Apis mellifera), leaf cutter bees (Megachile rotundata), alkali bees (Nomia melander) and bumblebees (Bombus spp.) (Rincker et al., 1988). Honeybee-mediated long-distance dispersal of pollen from alfalfa seed and hay production fields has been confirmed for distances up to $1000 \mathrm{~m}$ (St. Amand et al., 2000). In a similar study, Teuber et al. (2004) found outcrossing levels of $1.5 \%$ at $270 \mathrm{~m}$ and $0.2 \%$ at $1.5 \mathrm{~km}$, and were able to detect outcrossing as far as $4 \mathrm{~km}$, although at a very low level. Under leaf cutter bee pollination, Fitzpatrick et al. (2003) observed outcrossing levels of $1.4 \%$ at $152 \mathrm{~m}$, and only $0.28 \%$ at $274 \mathrm{~m}$, with no outcrossing at $610 \mathrm{~m}$. In the same study, a single outcrossing event was detected at $804 \mathrm{~m}$, at a very low frequency. These studies demonstrate the long-distance dispersal potential for gene exchange among alfalfa fields. Further, the introduction of pollinator insects for alfalfa seed production in the border regions would increase the opportunity for pollen-mediated gene flow.

Feral alfalfa populations occurring in unmanaged habitats may further enhance the extent of long-distance gene flow by acting as bridges for the bees (Putnam, 2006). Feral crop species are those from which individuals escape a managed area to survive, reproduce and establish self-perpetuating populations in either natural or semi-natural habitats (Bagavathiannan and Van Acker, 2008). With their deep root system, symbiotic nitrogen fixation, prolific seed production and prolonged seed dormancy, alfalfa plants are capable of establishing self-perpetuating populations in unmanaged environments. Their perenniality, quick regrowth potential, drought- and winter-hardiness may further contribute to their success in the natural areas and their ability to form effective feral sub-populations within agricultural landscapes (Bagavathiannan and Van Acker, 2009). Our current research in Western Canada suggests that alfalfa is capable of establishing self-perpetuating feral populations (Bagavathiannan et al., 2009) and they may act as the sources and sinks for the movement of GM traits from fields of GM alfalfa to fields of non-GM alfalfa (Bagavathiannan et al., 2008).

We hypothesize that there exists the possibility for the GR trait to move from GM alfalfa fields in the US to nonGM alfalfa fields in Canada. This movement would most likely happen in situations where alfalfa fields and/or the feral alfalfa populations are located on both sides of the border close enough to allow for effective cross pollination. The width of the US-Canada border area within many of the farmed regions is less than $10 \mathrm{~m}$ in many cases (Fig. 1). Such a distance suggests that international gene flow could occur readily from GM alfalfa in the US to non-GM alfalfa in Canada.

The US and Canada share $2878 \mathrm{~km}$ of land border from the Atlantic to the Pacific Ocean (IBC, 2007). The border includes the US states of Maine, New Hampshire, Vermont, New York, Pennsylvania, Ohio, Michigan, Minnesota, North Dakota, Montana, Idaho and Washington. Alfalfa is commonly cultivated in most of these states, and the details on the current existence of GR alfalfa fields in counties adjacent to the Canadian border are presented in Table 1. On the Canadian side, alfalfa has been widely cultivated in southern parts of all of the land-border provinces including New Brunswick, Quebec, Ontario, Manitoba, Saskatchewan, Alberta and British Columbia (Fig. 2).

We carried out a short survey along the USCanada border in two rural municipalities (Rhineland and Franklin) in southern Manitoba, Canada to see if there 
Transgenes and national boundaries

Table 1. Occurrence of GR alfalfa fields in counties adjacent to the Canadian border*.

\begin{tabular}{|c|c|c|}
\hline State & Border counties with Canada & $\begin{array}{c}\text { Counties where } \\
\text { GR alfalfa fields occur }\end{array}$ \\
\hline Washington & 4 (Clallam, Island, San Juan, Whatcom) & 2 (Island, Whatcom) \\
\hline Idaho & 1 (Boundary) & No \\
\hline Montana & $\begin{array}{c}11 \text { (Lincoln, Flathead, Glacier, Toole, } \\
\text { Liberty, Hill, Blaine, Phillips, Valley, } \\
\text { Daniels, Sheridan) }\end{array}$ & $\begin{array}{c}8 \text { (Glacier, Toole, Liberty, Hill, } \\
\text { Blaine, Phillips, Valley, Daniels) }\end{array}$ \\
\hline $\begin{array}{l}\text { North } \\
\text { Dakota }\end{array}$ & $\begin{array}{l}8 \text { (Divide, Burke, Renville, Bottineau, } \\
\text { Rolette, Towner, Cavalier, Pembina) }\end{array}$ & $\begin{array}{c}5 \text { (Divide, Burke, Bottineau, } \\
\text { Cavalier, Pembina) }\end{array}$ \\
\hline Minnesota & $\begin{array}{l}7 \text { (Kittson, Roseau, Lake of the woods, } \\
\text { Koochiching, St. Louis, Lake, Cook) }\end{array}$ & 2 (Kittson, Roseau) \\
\hline Michigan & 2 (Chippewa, St. Clair) & 1 (St. Clair) \\
\hline New York & $\begin{array}{c}5 \text { (Orleans, Jefferson, St. Lawrence, } \\
\text { Franklin, Clinton) }\end{array}$ & 1 (St. Lawrence) \\
\hline Vermont & 4 (Grand Isle, Franklin, Orleans, Essex) & None \\
\hline New Hampshire & 1 (Coos) & No \\
\hline Maine & 1 (Aroostock) & No \\
\hline
\end{tabular}

Source: APHIS (2008).

*Details on the exact locations of GR alfalfa fields are not made available to the public by USDA. Therefore the fields may or may not be located closely adjacent to the international border. However, the information provided in the above table is the best available at this time.

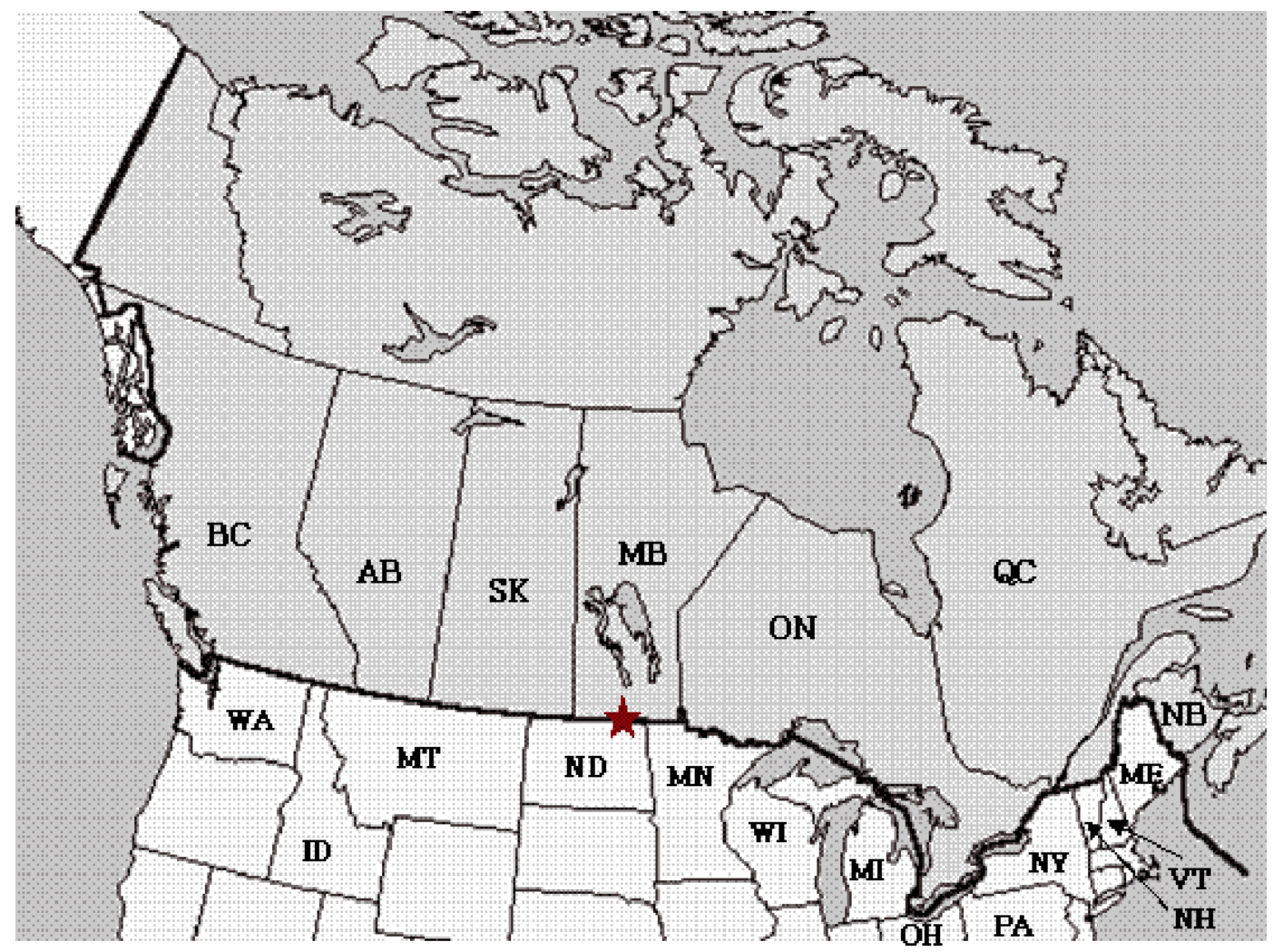

Figure 2. The states and provinces along the US-Canada border from the Atlantic Ocean to the Pacific Ocean. The star denotes the area where the survey described in this paper was done (photo courtesy: International Boundary Commission). 
M. Bagavathiannan, R. Van Acker

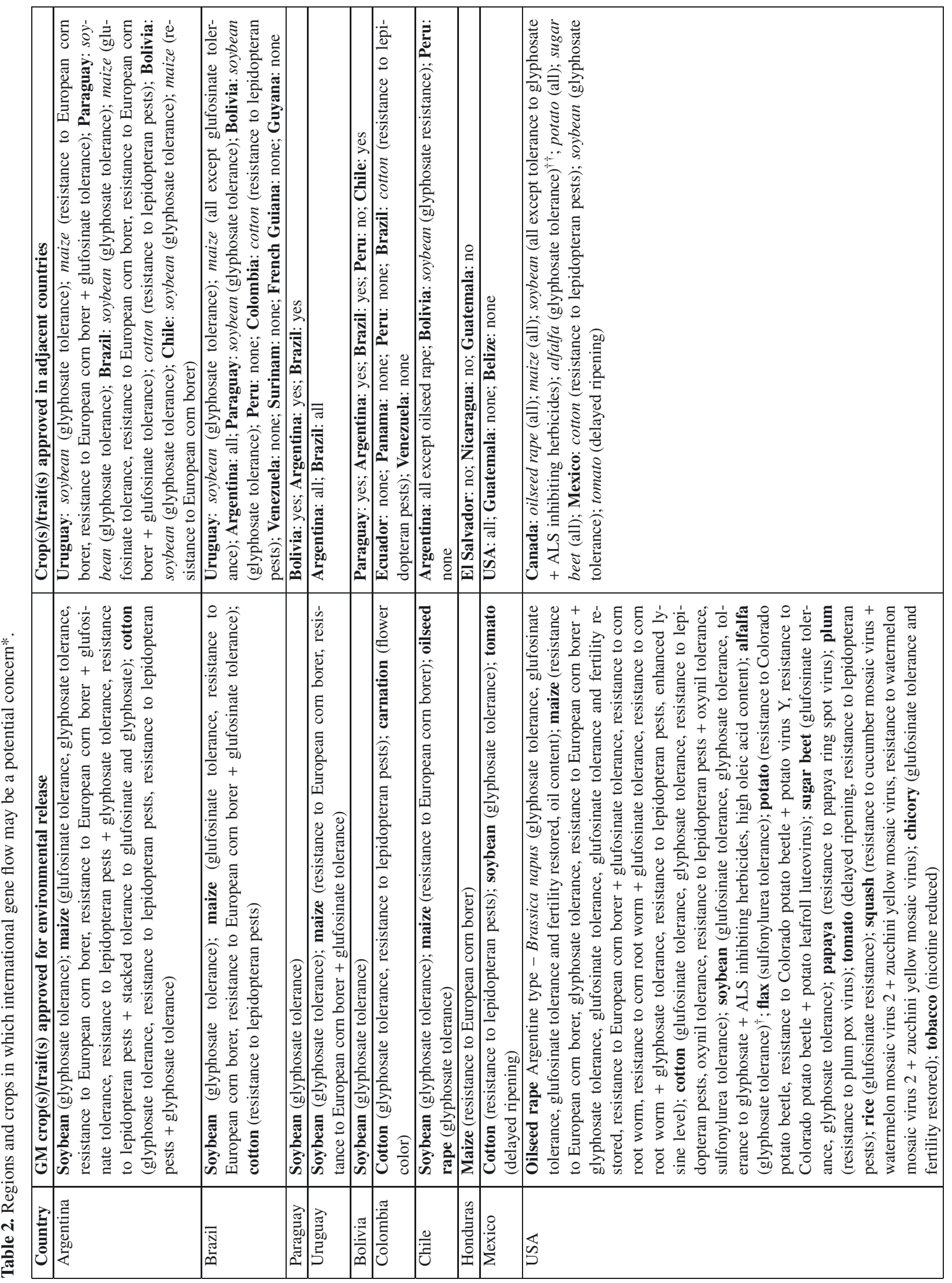




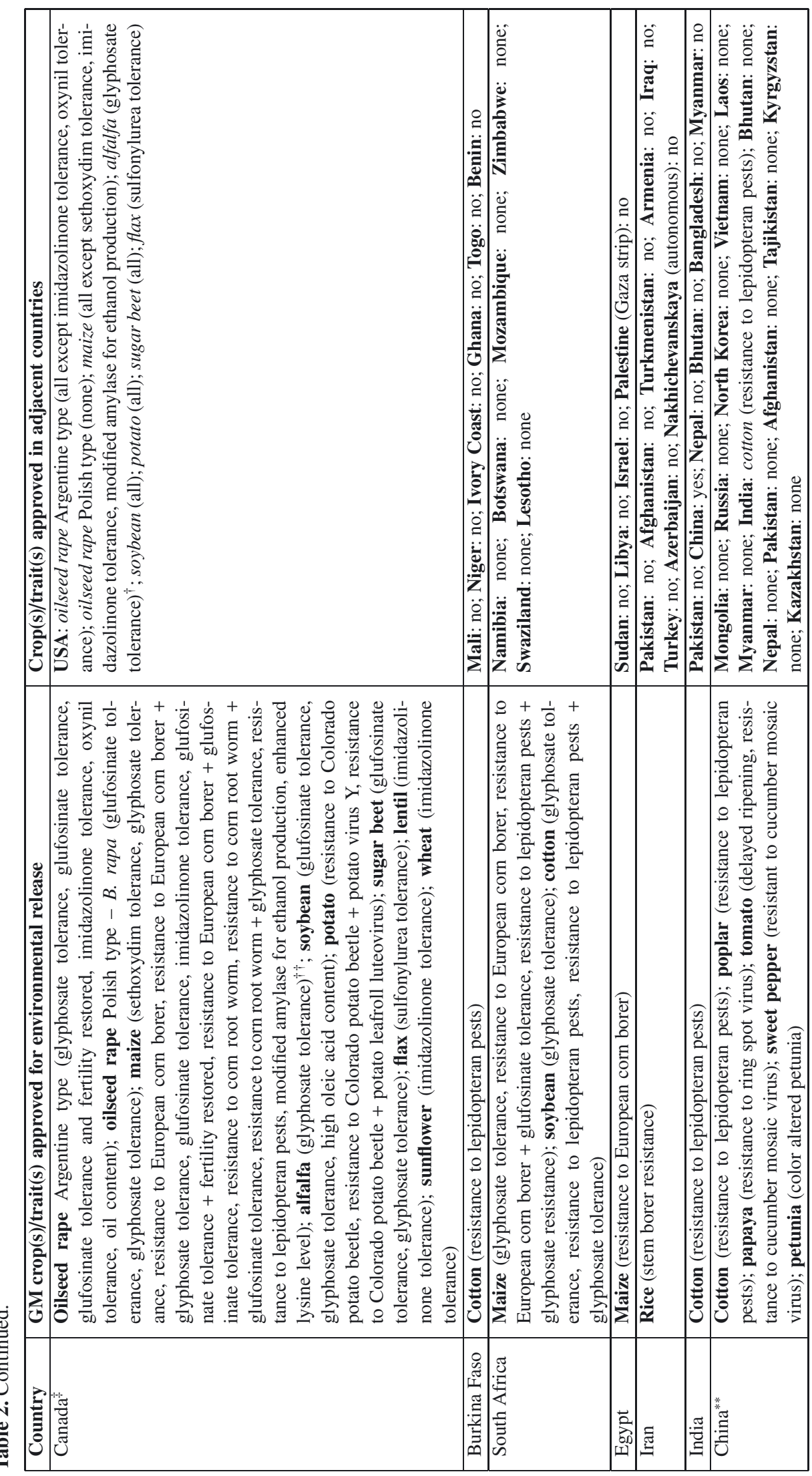



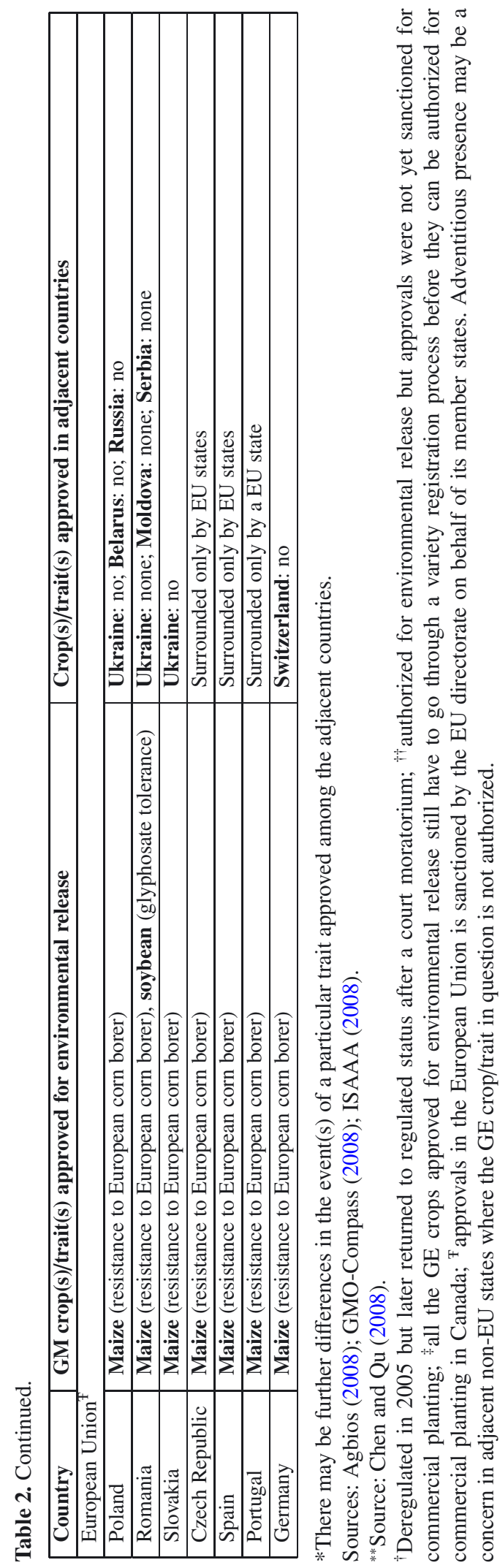

were alfalfa fields and potentially feral alfalfa plants (alfalfa plants outside of cultivated fields) in cross-border locations that might facilitate international gene flow. We drove along border roads (a distance of about $50 \mathrm{~km}$ ). We found alfalfa fields and potentially feral alfalfa plants in the ditches along the border (Fig. 3). In one of the municipalities (Rhineland), within a survey distance of $12 \mathrm{~km}$, we found two alfalfa fields on the Canadian side of the border and two potentially feral alfalfa populations (population sizes of 10 and 15) in the ditch along side the border immediately adjacent to the alfalfa fields. We also found one potentially feral alfalfa population (6 plants) located on the US side only $800 \mathrm{~m}$ from an alfalfa field. In the other municipality (Franklin), we found a large potentially feral alfalfa population (18 plants) and three smaller populations (3-5 plants each) in a survey distance of $16 \mathrm{~km}$, but we did not find any nearby cultivated alfalfa fields.

Our survey results provide evidence of the possibility of international alfalfa transgene flow from the US to Canada. However if transgenic alfalfa seed or alfalfa plants are found in Canada, the liabilities to such contamination are not clear. Who should bear the responsibility in the event of a transgene contamination? Canadian farmers or the Canadian government? Should US farmers move their fields away from the border? The ability of Canada to limit the risk of cross-border transgene flow via metapopulation dynamics requires knowledge of the location of transgenic crops. Currently, the GPS locations of cultivated GR alfalfa fields in the US are not publicly available in any database. Further, it is not clear whether such information would be revealed to the Canadian farmers through the call centers set up by USDA. The situation in the US has implications for Canada, when there is risk of transgene movement across the border. This perhaps points to a need for international cooperative risk assessment initiatives between the US and Canada, particularly for GM crop species which have a high ferality potential, are outcrossing (and insect pollinated), and are very commonly grown on either side of a shared land border.

We speculate that similar situations of international gene flow might occur for other GM crops, in other border regions as well. In Europe, the commercial approval of GM crops is governed by the European Union (EU) on behalf of its member states, and the issue of international gene flow among the EU member states may be considered insignificant. However, transgene flow across an international border could be a potential concern in other regions of the world, including non-EU member states, Asia, Middle East, South Africa and South as well as North America (Tab. 2). Thus, it is necessary to consider the implementation of additional regulatory measures for growing GM crops in border regions where 


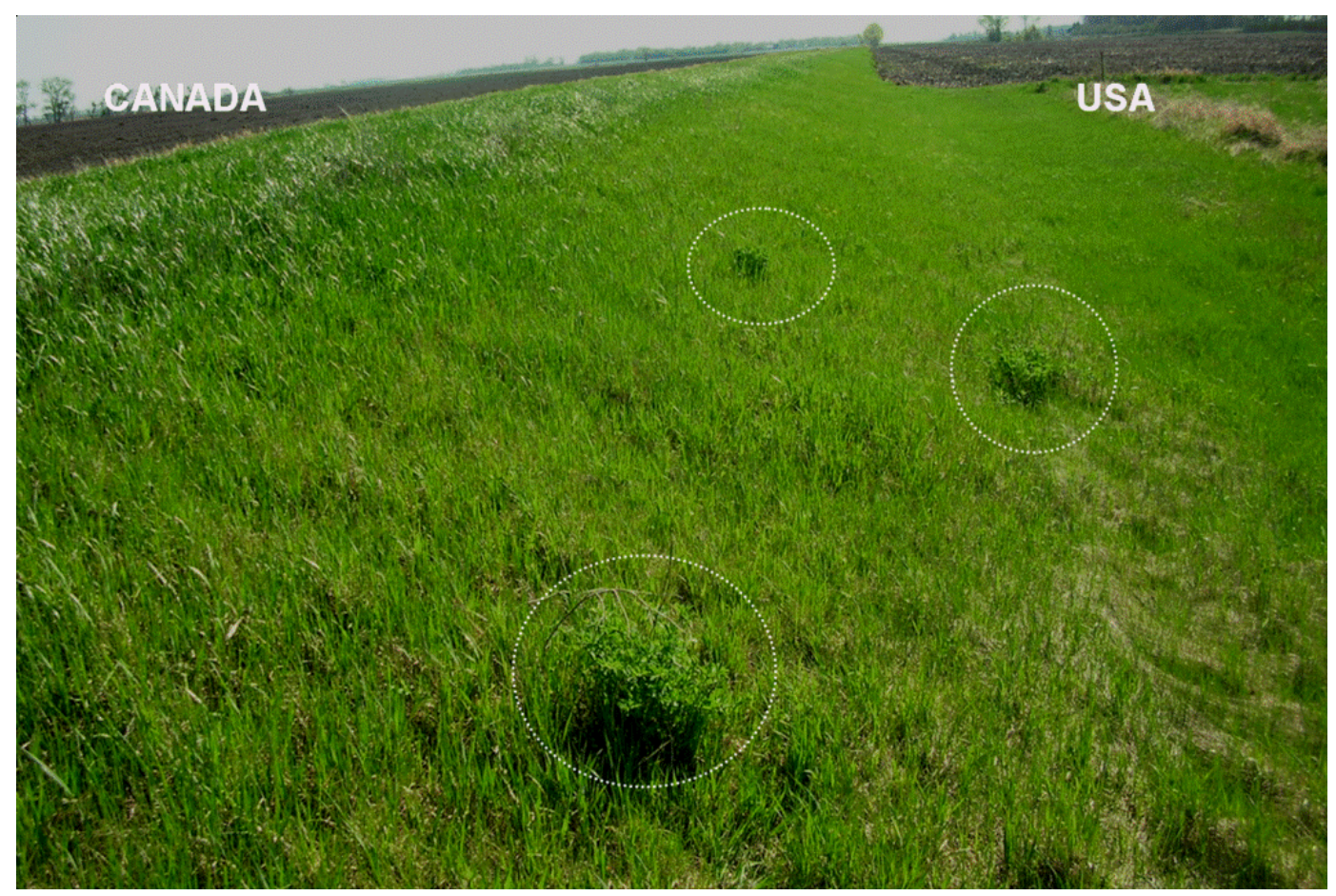

Figure 3. Potentially feral alfalfa plants in a ditch along the US-Canada border near Altona, Manitoba, May 2007.

international gene flow is a possibility. International cooperation and information sharing among the countries in question could resolve how to deal with this possibility. Furthermore, the possibility of international gene flow should be considered as an essential component in the decision-making processes for the field release of any GM crop.

\section{ACKNOWLEDGEMENTS}

We thank the Agri-Food Research and Development Initiative (ARDI) of Manitoba Agriculture, Food and Rural Initiatives (MAFRI), University of Manitoba Graduate Fellowship (UMGF) and Manitoba Graduate Scholarship (MGS) for funding this study. We thank Dr. Norman Ellstrand for his valuable comments, which greatly improved an earlier version of this manuscript. We also thank Dr. Michelle Marvier, Santa Clara University, CA, for her inputs on this manuscript and Mr. Brian Jack, agricultural representative of Altona, MB for helping with the survey.

Received September 5, 2008; accepted February 2nd, 2009.

\section{REFERENCES}

Agbios (2008) Global status of approved genetically modified plants. http://www.agbios.com/dbase.php?action=Synopsis

Animal and Plant Health Inspection Service (APHIS) (2008) States and counties in which Roundup Ready alfalfa is produced. http://www.aphis.usda.gov/biotechnology/alfalfa_ locations.shtml

Bagavathiannan M, Van Acker R (2008) Crop ferality: Implications for novel trait confinement. Agric. Ecosys. Environ. 127: 1-6

Bagavathiannan M, Van Acker R (2009) Ecology and biology of feral alfalfa (Medicago sativa, L.) and its implications for novel trait confinement. Cri. Rev. Pl. Sci. 28: 69-87

Bagavathiannan M, Julier B, Barre P, Van Acker R (2008) Estimation of genetic diversities among different feral alfalfa (Medicago sativa L.) populations occurring in Southern Manitoba, Canada using SSR markers. Proceedings of the 62nd Annual Meeting of the Canadian Weed Science Society, Banff, Alberta, Canada

Bagavathiannan M, Gulden R, Begg G, Van Acker R (2009) The demography of feral alfalfa (Medicago sativa, L.) populations occurring in Southern Manitoba, Canada. Proceedings of the Weed Science Society of America Annual Meeting, Orlando, FL, USA

Chen Z, Qu L (2008) The status of agriculture biotechnology in China. http://www.gmo-safety.eu/pdf/biosafenet/ Zhang-Liang.pdf 
Fitzpatrick S, Reisen P, McCaslin M (2003) Pollen-mediated gene flow in alfalfa: A three-year summary of field research. Proceedings of the 2003 central alfalfa improvement conference, virtual meeting July 21-25, 2003. http://www.naaic. org/meetings/central2003/Gene-flow_in_Alfalfa_Abstract_ final.doc

Fox J (2007) US courts thwart GM alfalfa and turf grass. Nat. Biotech. 25: 367

GMO-Compass (2008) Global GM planting in 2007. http:// www.gmo-compass.org/eng/agri_biotechnology/gmo_ planting/257.global_gm_planting_2007.html

International Boundary Commission (IBC) (2007) The international boundary between Canada and the United States. http://www.internationalboundarycommission.org/ ibcpg2.htm\#contacts

International Service for the Acquisition of Agri-Biotech Applications (ISAAA) (2008) Highlights of the global status of commercialized biotech/GM crops. http://www.isaaa. org/resources/publications/briefs/39/highlights/default.html

Putnam D (2006) Methods to enable coexistence of diverse production systems involving genetically engineered alfalfa. Agricultural Biotechnology in California Series, Publication 8193. Available at http://ucanr.org/freepubs/docs/8193.pdf

Rincker C, Marble V, Brown D, Johansen C (1988) Seed production practices. In Hanson A, Barnes D, Hill R, eds, Alfalfa and alfalfa improvement, American Society of Agronomy, Inc. Publishers, Madison, Wisconsin, USA, pp 985-1022

St. Amand P, Skenner D, Peaden R (2000) Risk of alfalfa transgene dissemination and scale-dependent effects. Theor. Appl. Genet. 101: 107-114

Teuber L, Van Deynze A, Mueller S, McCaslin M, Fitzpatrick S, Rogan G (2004) Gene flow in alfalfa under honey bee (Apis mellifera) pollination. http://www.foragegenetics.com/pdf/ 4RRANAAICAbstractTeuberGeneFlow.pdf

United States District Court (USDC) (2007a) Preliminary injunction order report from the United States District Court for the Northern District of California, order No. C 06-01075 CRB, dated March 12, pp 1-15

United States District Court (USDC) (2007b) Memorandum and order re: permanent injunction report from the United States District Court for the Northern District of California, order No. C 06-01075 CRB, dated May 3, pp 1-15

United States District Court (USDC) (2007c) Amended judgment report from the United States District Court for the Northern District of California, San Francisco division, case no. 3:06-cv-01075-CRB, dated July 23, pp 1-4

Western Organization of Resource Councils (WORC) (2005) The problem with GM alfalfa: A fact sheet. http://www.worc.org/pdfs/ The $\% 20$ Problem $\% 20$ with\%20GM\%20Alfalfa.pdf 